\title{
Positive affect in young children's multiliteracies learning endeavors
}

\section{Nordström, Alexandra}

Routledge

2019-09-12

Nordström , A , Kumpulainen , K \& Potter , J 2019 , Positive affect in young children's multiliteracies learning endeavors . in K Kumpulainen \& J Sefton-Green (eds), Multiliteracies and Early Years Innovation : Perspectives from Finland and Beyond . Routledge Research in Early Childhood Education, Routledge, London , pp. 166-182 . https://doi.org/10.4324/9780429432668-10

http://hdl.handle.net/10138/319302

https://doi.org/10.4324/9780429432668-10

unspecified

acceptedVersion

Downloaded from Helda, University of Helsinki institutional repository.

This is an electronic reprint of the original article.

This reprint may differ from the original in pagination and typographic detail.

Please cite the original version. 
Please cite: Nordström. A. Kumpulainen, K. \& Potter, J. (2019). Positive affect in young children's multiliteracies learning endeavours. In K. Kumpulainen and J. Sefton-Green (Eds.), Multiliteracies and Early Years Innovation: Perspectives from Finland and Beyond. Routledge Research in Early Childhood Education. London: Routledge.

\title{
Positive affect in young children's multiliteracies learning endeavours
}

Alexandra Nordström, Kristiina Kumpulainen and John Potter

\begin{abstract}
This chapter focuses on the processes and conditions for the emergence of positive affect during children's multiliteracies learning endeavours in a Finnish pre-primary school which culminated in an exhibition at a local library. It identifies three thematic categories of activity which correlated strongly with positive, affective outcomes, namely: making and producing, sharing experiences and sustaining interest. The chapter demonstrates how positive affect is evoked when children are afforded opportunities to create, make, and share different texts and interests in the course of their multimodal, multisensory and playful activities, developing skills and dispositions of competence, relatedness and agency.
\end{abstract}

\section{Introduction}

According to the World Happiness Report (2018), Finland is the happiest country in the world. Finland is also ranked as the world's most literate nation with active use of public libraries (Miller \& McKenna, 2016). So why are we dedicating this chapter to considering enjoyment in children's literacy learning in a Finnish classroom? Aren't children in Finland already happy and well supported to become literate?

In the midst of flattering international news about the Finnish nation and its universal public services and accomplishments, there is a growing concern in Finland about children's and young people's declining interest in print-based literacy, as well as the widening variation in young people's reading habits and multiliteracies skills (Mullis et al., 2017; PIRLS, 2016, see also the Introduction to this volume). To tackle these challenges, a National Literacy Forum 
was established in 2017 by the Finnish government to develop a national strategic plan and a so-called national literacy movement, to promote children's and young people's "reading for pleasure" in Finland. This initiative advocated strengthening the collaboration between homes, early childhood education (ECE) centres, schools, libraries and other cultural institutions for the cultivation of a literate and happy nation.

As the Introduction chapter to this volume explains, alongside these efforts, the Finnish new national core curricula introduced multiliteracy as one of the transversal competences to be promoted by teachers across subject areas. Nevertheless, in this chapter we use the notion of multiliteracies, which suggests a multitude of literacies and social practices (e.g. Serafini \& Gee, 2017). The Finnish curricula for children aged 0 to 8 also prescribes a playful and multimodal approach to teaching and learning, and states that children have the right to enjoy learning: "In pre-primary education, children learn by playing, moving, exploring, by working on different assignments, expressing themselves, and through activities based on arts. Positive emotional experiences, joy and creative activities promote learning and inspire children to develop their own competence." (EDUFI, 2016, p. 33).

Further, the title of the Finnish research and development programme, 'The Joy of Learning Multiliteracies', points to the significance of children's enjoyment and positive affect in learning. This title of the program was chosen "to communicate the motivation, diversity and tolerance behind both learning and teaching multiliteracy skills as well as the joy of being, doing and practicing things together" (Kumpulainen et al., 2018, p. 4). In this chapter, our academic interest lies in exploring children's positive affect, regarding the joyful dimensions of multiliteracies learning. That is, 'the joy of being and doing things together'.

Therefore, in our chapter, we take positive affect seriously and consider how a pedagogy of multiliteracies influenced by the original work of the New Literacies (New London Group, 1996) can create opportunities for children to enjoy and engage in their multiliteracies learning. In our research, we ask; How does positive affect manifest itself in children's multiliteracies learning endeavours? and specifically How does the pedagogy of multiliteracies create opportunities for positive affect to emerge?

Our work draws on an exploratory case study of children of pre-primary school age (6 years old in Finland) and their engagement in a creative and multimodal literacy project situated in a Finnish pre-primary classroom and the local library. We regard our research as important and needed not only in Finland but more globally since 'positive affect' is increasingly 
acknowledged as an important component for learning and human functioning in general. Positive emotions, for example, have been shown to broaden an individual's thought-action repertoire, which can include novel thoughts, activities, and relationships (Fredrickson, 2001), all of which can potentially be generative of rich learning. However, surprisingly little research attention has been directed to understanding and conceptualising how positive affect emerges in the pedagogical design and undertaking of young children's literacy learning activities, and it is this gap in knowledge which we attend to in this chapter.

We begin our chapter with a brief overview of the relevance of 'affect' in education and learning. Drawing on illustrative examples from a multiliteracies project, the chapter makes salient the social nature of children's positive affect supported by the multiliteracies pedagogy. These illustrative cases also make visible how researching and understanding positive affect in children's learning endeavours is a powerful gateway to understanding children-their experiences, worldviews and orientations-all of which account for their interactions with and learning of multiliteracies.

\section{Conceptualising and researching affect as social practice and interaction}

Although research on affect and emotions is on the rise in psychological and educational fields of inquiry (Seligman \& Csikszentmihalyi, 2000; Seligman et al., 2009), overall, research on young children's emotions in education is still fairly scarce (i.e. Zembylas, 2016). Yet, emotions are known to be an integral element of meaning-making as they arise from social practices and convey meanings to oneself and others (Oatley, 1993). Social psychologists Mesquita and Albert (2007) point out how social contexts in which emotions are constructed are mediated by cultural norms with specific emotional display rules. Following this line of thinking, it becomes important to investigate not only whether and how affect and emotions are expressed and shared in social interactions, but also how they are recognised and responded to in moment-to-moment interactions (Kelly, 2016).

Earlier research in the field has shown that positive emotions contribute to children's ability to innovate, their creativity and their skills in problem-solving (see also Konu, 2002; Liu et al., 2014; Murray \& Palaiologou, 2018; Fredrickson, 2003; Pekrun et al., 2006). There is also evidence that children's positive emotional experiences in educational settings are connected to their opportunities to participate and affect their environment and their academic 
achievement (Fredrickson, 2001; Kangas, 2010; Kumpulainen, Lipponen, Hilppö, \& Mikkola, 2014; Kumpulainen, Mikkola, Rajala, Hilppö, Lipponen, 2014).

In this chapter, affect is regarded as an overarching concept that encompasses emotions and moods shaped in social and evolutionary contexts (Schuman \& Scherer, 2014). Affect can be understood as social events that are evoked by various stimuli and which are often about an urgent and personal matter at hand (Ekman, 1992; Keltner \& Gross, 1999; Scherer, 2009). To experience positive affect in the form of enjoyment can also encompass feeling pleased about one's participation in activities, and being able to exercise and expand ideas, knowledge and actions (Fredrickson 2001; Izard, 1977). Furthermore, positive affect can be evoked in situations where one achieves, or progresses towards, one's goal (Izard, 1977).

Even though affect includes a private component, it also has a significant social aspect and is therefore regarded as social and cultural practice rather than a psychological state (Ahmed, 2014). In fact, there is an emerging body of research that describes affect, including pleasure and enjoyment, as culturally embedded and socio-materially constructed in interaction with others (see e.g. Canovi, Rajala, Kumpulainen, \& Molinari, in press; Fleer, Gonzalez Rey, \& Veresov, 2017; Stone \& Thompson, 2014). Furthermore, Kelly (2016), drawing on sociocultural theory, describes emotional expressions as interactional, contextual, intertextual and consequential, as well as identifiable in ongoing discourse; in other words, in a situation where emotions are expressed, shaped and shared. In turn, Ahmed (2014) discusses the 'sociality of emotion' and argues that shared feelings are not necessarily about feeling the same, rather she suggests that it is the objects of emotion that circulate, rather than emotion as such, and that "such objects become sticky, or saturated with affect, as sites of personal and social tension" (Ahmed, 2014, p. 11).

The conceptual framing proposed in this chapter which facilitates an understanding of positive affect in young children's multiliteracies learning endeavours, draws on the sociocultural conceptualisation of affect and emotions, as well as Self-Determination Theory (SDT) of motivation and optimal functioning. Whereas, the sociocultural framework advocated by our work underscores affect as a social construct that manifests itself in evolving interactional activity embedded in the socio-material context (Canovi, Rajala, \& Kumpulainen, in press; Kelly, 2016). SDT focuses on how cultural and social conditions relate to an individual's intrinsic motivation, interest and wellbeing. According to SDT, an individual's experience and psychological need of competence, relatedness, and autonomy is 
connected to volitional forms of motivation for and engagement in social activities.

Subsequently, these three innate psychological needs, when achieved, enhance positive affect, such as motivation and enjoyment (Ryan \& Deci, 2000).

\section{Introduction to the Spirits of the Forest project}

The Spirits of the Forest project was undertaken in a Swedish-speaking municipal preprimary school in an urban area in Southern Finland as part of The Joy of Learning Multiliteracies Research and Development Programme (MOI-programme) ${ }^{1}$. The project lasted for a period of three months and it was a part of a larger local programme entitled 'Nature and Finland 100-years' that all early childhood education centres, pre-primaryschools, and primary schools in that area took part. The project drew upon the Whisper of the Spirit material (Erfving et al., 2017; see Figure 1), familiarizing children with Finnish stories, nature, myths and ancient beliefs from a variety of perspectives. The material encourages children to imagine, observe, collaborate, reflect, innovate and experiment (see also Chapters 3 and 6).

The participants in the project were nine children aged six years, one teacher and one child care provider. Participation in the study was voluntary, and full, prior written consent was obtained from the teachers and guardians of the pre-primary school children ${ }^{2}$.

\section{INSERT FIGURE 1 HERE}

The Spirits of the Forest project drew on the pedagogy of multiliteracies and entailed the preprimary group experiencing the forest, the different materials and the social context, conceptualizing around the notions and concepts of spirits, elves, trolls and other mythical creatures, as well as emotions and friendship. The project introduced the children to nature

\footnotetext{
${ }^{1}$ The area served by the pre-primary school is an ethnically and linguistically diverse community, albeit all children spoke one of Finland's official languages (Finnish and Swedish) as their first language. Many of the children were bilingual (speaking both Swedish and Finnish at home).

2 The study was conducted according to the responsible conduct of research following the ethical guidelines of the Finnish Advisory Board on Research Integrity (Tutkimuseettinen neuvottelukunta [TENK], 2012).
} 
conservation, and how to be a good friend through analysing different actions, interaction and meanings, transferring and applying their knowledge about nature, friendship, and interaction when designing, making and displaying (see Figure 2) their own spirits of the forest and interpreting the meaning of these spirits for the Finnish forests and nature.

\section{INSERT FIGURE 2 HERE}

Although playful and experiential child-centred learning is at the heart of Finnish early childhood education, it is important to note that the Spirits of the Forest project was distinctively different from everyday practice, not only in this pre-primary classroom, but even nationally. The uniqueness is evidenced in that, first, the multiliteracies project extended across the ECE center, local forest and the library. Second, the pedagogical material of the Whisper of the Spirit introduced the children with Finnish myths around the forest guided the children's orientation, investigation and imagination of their environment in novel ways.

According to the teachers themselves, the project differed from everyday practice, with the children being more engaged in the decision-making, and in the collaboration with the library and other ECE and schools in the area. Promoting young children's multiliteracies and emotional skills via an integrated, three-months-long project situated across the classroom, the forest and the library spaces was a novel effort. Furthermore, using and remixing multiple modalities and literacies from traditional print-based books and stories on the subject, to searching for information online, creating digital stories behind QR codes, and seeing a play_all as part of a theme-based project—were all novel. Designing an exhibition for display at a local library and expanding children's participation and agency in the community, contributed to the novelty of the project compared to a more standard Finnish early childhood education practice. Overall, the project very much modelled the new Finnish curriculum requirements, and arguably demonstrates one model of future everyday practice in Finnish early childhood education.

\section{Illustrations of children's positive affect during multiliteracies learning endeavours}


Next, we will provide illustrative examples of the project in action and consider how the conditions for positive affect were brought into being in the course of the work. The data corpus consists of observational field notes, photographs, children's artefacts and interviews conducted with the children and teachers. The methodological approach that guided the analysis was embedded in an ethnographic perspective (Gee \& Green, 1998). Given the nature and limitations of the data, the interpretations proposed are tentative, which, whilst grounded in the actions of, and interviews with, the children and teachers, should nevertheless be viewed as illustrative descriptions. The results are reported here as indicative of manifestations of, and pedagogical conditions for, young children's enjoyment and engagement in multiliteracies learning endeavours.

We have divided our illustrations into three thematic categories, illustrating multiliteracies practices in which positive affect was provoked, apparent and detectable in the children's social activity. These three thematic categories illustrate the following: positive affect in making and producing, in sharing experiences and in sustaining interest. Taken together, they make visible how positive affect was generated through the children's sense of competence, relatedness, and autonomy in the learning activities. Our selection of these illustrative examples is not exhaustive, rather the purpose is to demonstrate how manifestations of young children's enjoyment were provoked through designed multiliteracies pedagogy. We are presenting them in order to make salient the pedagogical acts of both multiliteracies pedagogy, and the positive affective outcomes of these acts.

\section{"Even if it is not real for real": Positive affect in making and producing}

Our first example shows how positive affect emerged in activities where the children were given opportunities to act agentively and competently in making and producing meaning and artefacts, using their imagination and creativity. An important part of the meaning-making was the situated practice of linking the material and activities with the children's own experiences, reflections and storying about the forest and nature; this enabled them to experience both the known and the new in a safe and supportive environment. Furthermore, the children's 'own forest', Mulleskogen (see Figure 3), which they visited on a regular basis, was an important part of the project, as it placed the notions of myths and spirits in a familiar context for the children. The group made trips to the forest and collected materials from nature for their spirits. They experienced these in multimodal and sensory ways; they smelled, felt and, in some cases, tasted the different materials, enhancing the different ways 
of making meaning. The children also played a game in the forest which developed their interaction and play by engaging them in dialogue and physical contact with each other and the forest itself.

\section{INSERT FIGURE 3 HERE}

In the following account, the pre-primary school teacher, $\mathrm{Kia}^{3}$, considers how the idea of the actual project came to be, and how the children's interests steered and contributed to the theme during the project. These pedagogical principles also echo efforts to create opportunities for children to enjoy their engagement, since positive emotions are typically evoked in situations where one achieves, or progresses towards, one's goal (Izard, 1977).

Kia: We started the project with the children, with looking at totem poles on a tablet and discussing what else we have here in Finland. We talked about the Finnish sauna elves and home elves. From there, the idea of the spirits of the forest came. The ideas have come from the children. The children also chose what materials they wanted to use and collected them from the woods. They had clear visions from the beginning on how to make their spirits.

The children were encouraged to use different materials and a variety of tools and techniques, and this open-endedness provided opportunities for innovative, creative and transformative practice in the designing and making processes. Figure 4 illustrates Mary designing, sketching and making her spirit which she named Aukki, the Spirit of the Trees.

INSERT FIGURES 4.1, 4.2 and 4.3 HERE

Earlier research has suggested that when children are given the opportunity to actively engage in imaginative activities that have personal relevance, and actively participate in and influence their environment, they are likely to experience positive emotions (Kangas, 2010).

\footnotetext{
${ }^{3}$ All participants' names are anonymized.
} 
Children's creative engagement with multimodal texts also lays a foundation for their literacy development as they interact with others, use tools, toys and materials symbolically, create narratives and stories and make rules and roles for play (Sintonen et al., 2018; White, 2012). Imagination and creativity can open up new worlds and forms of thinking in which children can surpass their own level of understanding and create a zone of proximal development (Vygotsky, 1962).

The children's positive affect was fuelled by their excitement and enthusiasm in their discussions about making their spirits, where the children's creativity and imagination flourished, as demonstrated here by Linnea's and Amalia's accounts:

Researcher: Linnéa, what will your spirit be like?

Linnéa: We were going to glue a bird on its shoulder like this [points to her own shoulder], sitting, and it has birds on its dress, and what is it called... It kind of stands, and yeah it has a bird, because it likes birds a lot, and that's also why it has a bird necklace, which I am going to make out of thread, and then I will make a bird there.

Amalia: I mean, the birds aren't alive for real, the birds, but in make-believe they are real... You could play that it is real, that bird on the shoulder, also the one on the dress, but not the one in the necklace, because...

Linnéa: [interrupts] I mean, they are not alive, they are like pictures on the dress [gestures to her own dress], pictures of birds, and then there is a real, live bird on the shoulder, even if it is not real for real.

The children's accounts emphasised the range of material artefacts available to them and the role that they played for their heightened emotions and the construction of meanings in the activity. Here, the materials and activities kindled the children's creativity, imagination, and an urge to play.

“Please come see my Spirit!”: Positive affect in sharing experiences

Our second example shows how positive affect emerged in interaction with others, evidencing a need and sense of relatedness among the children and their teachers (see also 
Ryan \& Deci, 2000). Being able to share and be part of the community is evidenced, for example, in Mary's excitement and eagerness in sharing her work and experiences with others. In the following excerpt from field notes, Mary proudly and happily shares her experiences with the researcher of her own volition:

I visited the pre-primary school to collect some video data, and when I enter, I see that one child, Mary, is sitting alone by a table, in the midst of making her spirit. She waves to me and asks me to come and see what she is doing. Mary is smiling and seems excited as she explains and shows that this is her spirit, and that she has collected the materials from the forest herself. She also shows her sketch of the spirit and explains what the spirit protects and how she is going to make the spirit according to her sketch. She also says that, in order for her to finalize her spirit, she needs an adult's help in gluing the pieces together, as the glue in the glue gun gets really hot and is only to be used by adults. She wonders if I could help her with the gluing so she can continue with the spirit, as it also takes some time for the glue to dry, and she is eager to get her spirit finished so it starts protecting the forest.

Whilst the project focused on the children creating their own individual artefacts, it was nevertheless a collective endeavour for the group. Hence, the positive affect that emerged was not confined within an individual, but was constructed in interaction between the children, and between children and their artefacts. This relatedness and sense of community also extended to caring for the forest, as can be seen in the following accounts from two children, Nellie and Mary, which illustrate the children's motives and emotional sensemaking of their spirits.

Researcher: Why have you chosen to make spirits for these things? Do you think they are important in some way?

Nellie: They are really important in some way. They kind of protect the whole nature. Mary: Yes, you are not allowed to saw down trees because the trees do not feel good about that. And, you are also not allowed to take leaves from the trees.

Nellie's and Mary's interaction in the interview points to their analysis of the concept of nature conservation and their own experiences from Mulleskogen. The children also displayed joint concern about, and an emotional relationship to, nature, as, for example, when 
they considered how the trees felt about being cut down, showing empathy with the natural world (see Chapter 6).

The story about Totti Stonemountain: Positive affect in sustaining interest

Our third example makes salient how positive affect was enhanced by activities based on the children's interests, and shows how they created spaces for the children's agency. The children's expressions of positive affect appeared when they were encouraged to choose which materials and methods to use in making the spirits as well as when they wanted to work on them. When teachers value children's choice, autonomy and agency, in contrast to controlling the activity, children's motivation, curiosity and desire for continued engagement increases, resulting in positive affect (see also Ryan \& Deci, 2000).

In the project, both children and their guardians were offered opportunities for active participation and decision-making. The teachers themselves also felt that the project was empowering and emancipatory for the children and their families, as expressed, for example, by the teacher, Kia:

The best part of this project has been how active the children have been, and how this nature theme has been a part of our pre-primary school activities for many months. The parents have also been active, sharing ideas and materials with us. The children have been very excited about this since the beginning, which made it so much fun for us as well.

The children's agency and continued interest in their activities in the project was also made visible by a child, Adam, who after creating his spirit decided to continue to write a story of his spirit character, thus continuing the narrative and spirit project. Adam's spirit, Bärtil, was a spirit of the stones. In the story, Totti Stenberg was a good friend of Bärtil's, and the surname, Stenberg, translated into English as Stonemountain. Figure 5 shows the last spread in Adam's storybook - the entire story that he had told Siri (Apple Inc.'s virtual assistant)— which was then printed by the teachers and glued into the storybook.

Adam's story was told as follows: 
Bärtil lived in a mountain. He slept in the rain. Totti Stenberg came to wake Bärtil up.

Then Bärtil and Totti walked to the rainbow and ran on the rainbow to the beach.

They played tag and grilled fish.

\section{INSERT FIGURE 5 HERE}

The children's agency and active role in the project accounting for positive affect was further enhanced by the public exhibition of the children's multimodally created artefacts at a local city library. The children designed the exhibition, supported by their teachers and the librarians, which supported their active, communal and independent learning in multiliteracies endeavours. Figure 6 illustrates the exhibition at the library. The visitors could view the material artefacts and listen to the children's presentations of their spirits by using the quick response $(\mathrm{QR})$ codes.

\section{INSERT FIGURE 6 HERE}

\section{Positive Affect and Literacy learning}

In this chapter, we have focused on the processes and pedagogical conditions for the emergence of positive affect in children's multiliteracies learning endeavours. Evidence from extant research suggests that positive emotional experiences in early childhood provide an important foundation both for children's academic learning and, more broadly, for a fulfilling life (Kumpulainen, Lipponen, Hilppö, \& Mikkola, 2012; Murray \& Palaiologou, 2018). Yet, surprisingly little attention has been directed to positive affect and its social conditions during children's engagement in literacy learning. In understanding the important role of the educational environment for children's positive experiences and affect we have discussed how the multiliteracies project and its distinct features engendered such processes. Specifically, we have demonstrated how positive affect was constructed into being in social situations when the children engaged in creating, making, and sharing different texts and 
interests in the course of their multimodal, multisensory and playful activities, accounting for their sense of competence, relatedness and agency.

Our work makes salient how the Finnish national core curriculum was operationalized in one pre-primary school when partnered with children's homes and local cultural institutions. The multiliteracies work outlined earlier project positioned the children as capable and active producers of cultural artefacts. It afforded children opportunities to turn into competent transformers of meaning, and meaning-makers in their own right (Cope \& Kalantzis, 2009). The pedagogy entailed rich and multimodal textual environments, including fairy tales, plays and stories, as well as constructing their own drama. The open-endedness of the activities allowed the children to take part in activities in different ways, which further contributed to their sense of competence, employing creativity, imagination and storytelling (Ryan \& Deci, 2000; see also Theory of Loose Parts, Nicholson, 1971). The project was built around learning environments that were flexible, comprehensive and designed to generate pedagogically coherent and interest-led themes. Appropriate challenges, feedback and the absence of performative and potentially demeaning assessment are all shown to facilitate children's intrinsic motivation and sense of competence and, subsequently, encourage the emergence of positive affect (Ryan \& Deci, 2000).

The children's sense of relatedness became evident in their creative and imaginative collective meaning-making. The pedagogical context supported the children's interaction and sense of security, and familiarity, including in the external environments of the local public library and the natural world. The multimodal approach encompassed the children designing and making with diverse tools and practices which, in turn, converged and intersected in their literacy practices. In this way, the children's creativity, imagination and collaboration with each other were supported (see also Jacobs, 2013; Kumpulainen, in press; Leander \& Boldt, 2013; Potter \& McDougall, 2017).

The pedagogical practices of the multiliteracies project in the study encouraged and developed the children's autonomy. They were supported and helped when needed, and the teachers provided the outlines of the activities in the project, but children were encouraged also to voice opinion and to decide on actions to be taken.

Further evident in the pedagogical context was that all emotions, both positive and negative, were valued. The children's autonomy was supported not only by encouraging them to make their own decisions, but also by being active and expressing their own opinions and feelings. 
The children themselves, for example, designed, collected the materials for, and created stories around, the spirits. According to the teacher, the children's ideas and interests guided the project, a statement that was supported in the realization of the project. The activities were nevertheless, to some extent, led and driven by the teachers, which raises further research questions around the degree of autonomy which would seek to build a body of evidence for children in such projects: how much autonomy, what kind, and with what results on positive affect and learning.

Clearly one of the teachers, Kia, was aware of the complexity of this issue, since, after the project, she reflected upon the pedagogical principles in the project as follows:

It is important... to be 'awake' as a teacher and to listen to the children so that it [project] will be meaningful for them. Then the project will be a success, and the children are excited because it's kind of their own thing that they are doing. And we [teachers] support and help them, but not instructing to 'do this or do that', because the ideas should come from the children, and that is what will make the project successful.

The notions of competence, relatedness and autonomy are all revealed as important factors in the design and reflection on practice.

Alongside making, tinkering, fixing and building with physical artefacts, children played with the form and function of various multimodal texts (Cannon, 2018). If they are able to coconstruct imaginative responses to the world in such a range of textual forms, they can, arguably, begin to extend their knowledge of what is possible. Because such settings admit the external culture and funds of knowledge that children bring with them across the 'semipermeable membrane' between home and school (Moll, Amanti, Neff, \& Gonzalez, 1992; Parry, 2013; Potter, 2011), they can become sites of 'porous expertise' wherein the children can present, explore and extend the knowledge of the world and each other which they bring with them into educational settings. These exchanges may also allow for learning gains at a range of depths and different locations. This underlines the potential value and importance of collaboration in settings of learning which has also been found elsewhere, in the context of cultural institutions, such as libraries and archives (Burn \& Richards, 2014).

Children's positive affect in their multiliteracies learning endeavours in this project can be described as participation in social practices, taking place in the literacy-rich environments 
created for and by children. Engaging in these spaces, including playing and learning together, arguably mediates interest in new phenomena, skills and knowledge, creating new forms of interaction. The findings in this setting do suggest that creative and multimodal play should be included in multiliteracies learning practices in formal education since it appears as a pivotal part of children's development and carries strong implications for children's intrinsic motivation and enjoyment.

\section{Conclusions}

When designing pedagogies and learning environments for multiliteracies learning, it is imperative to determine how they can be used to promote creativity through, in this case, positive affect; the emergence of creativity is not a given in any setting, but can be supported by the educational environment (Kumpulainen et al., 2010). Hence, the learning environment can be central to enhancing children's agentive activity and freedom, the creation of social relations, as well as generating meaningful and attainable goals (see also Rantala, 2006; Ryan \& Deci, 2000). As for the Finnish national strategies, the plans and developments to generate happy and literate citizens, we believe that multiliteracies pedagogies have the potential to prepare children from the earliest stages to develop the skills and dispositions to meet the needs of a complex and global society. We have seen in the project reported above, that this is complex and makes demands on all social actors in terms of resourcing and planning but that it is potentially highly rewarding in outcomes for the children involved.

Finally, since our goal as researchers and educators is to enhance children's deep engagement in and learning of multiliteracies, we believe that there is a need to attend to children's positive affect in settings of learning, regardless of topic or discipline. We hope that this chapter will contribute to, and suggest an agenda for, further research on a broader and deeper understanding of children's positive affect in educational settings. Further work will have to be conducted in order to explore the possible correlation between multiliteracies activities and positively affective outcomes. We therefore suggest that future research should be undertaken to investigate pedagogical designs and actions which support the emergence of positive affect in settings of learning from the earliest years and to learn more about the processes of multiliteracies pedagogy suggested by this chapter. 


\section{References}

Ahmed, S. (2014). The Cultural Politics of Emotion. Edinburgh: Edinburgh University Press.

Burn, A., \& Richards, C. (2014). Children's games in the new media age: Childlore, media and the playground. Farnham, UK: Ashgate.

Cannon, M. (2018). Digital media in education: Teaching, learning and literacy practices with young learners. London: Palgrave MacMillan.

Canovi, A., Rajala, A., Kumpulainen, K., \& Molinari, L. (in press). The dynamics of class mood and student agency in classroom interactions. Journal of Classroom Interaction.

Cope, B, \& Kalantzis, M. (2009). “Multiliteracies”: New Literacies, New Learning. Pedagogies: An International Journal, 4:3, 164-195, doi:10.1080/15544800903076044

Cope, B., \& Kalantzis, M. (2015). The things you do to know: An introduction to the pedagogy of multiliteracies. In B. Cope \& M. Kalantzis (Eds.), A pedagogy of multiliteracies: Learning by design, (pp. 1-36). London: Palgrave Macmillan UK.

EDUFI [Finnish National Agency for Education]. (2016). National core curriculum for preprimary education 2014. Publications 2016:6.

Ekman, P. (1992). An argument for basic emotions. Cognition and Emotion, 6, 169-200.

Erfving, E., Hintsa, A., Sintonen, S., Sairanen, H., \& Kumpulainen, K. (2017). Whisper of the spirit. Helsinki, Finland: Helsinki University Library.

Fleer, M., González Rey, F., \& Veresov, N. (2017). Perezhivanie, emotions and subjectivity: setting the stage. In M. Fleer, F. González Rey, \& N. Veresov (Eds.), Perezhivanie, emotions and subjectivity: Advancing Vygotsky's legacy. Perspectives in culturalhistorical research 1. Singapore: Springer.

Fredrickson, B. L. (2001). The role of positive emotions in positive psychology: The broaden-and-build theory of positive emotions. American Psychologist, 56, 218-226.

Fredrickson, B. L. (2003). The value of positive emotions: The emerging science of positive psychology is coming to understand why it's good to feel good. American Scientist, 91(4), 330-335. 
Fredrickson, B. L., \& Cohn, M. A. (2008). Positive emotions. In M. Lewis, J. M. HavilandJones, \& L. Feldman Barrett (Eds.), Handbook of emotions (pp. 777-796). New York: The Guilford Press.

Gee, J. P., \& Green, J. L. (1998). Discourse analysis, learning, and social practice: A methodological study. Review of Research in Education, 23, 119-169.

Halinen, I., Harmanen, M., \& Mattila, P. (2015). Making sense of complexity of the world today: Why Finland is introducing multiliteracy in teaching and learning. In Improving literacy skills across learning. Consortium of Institutions for Development and Research in Education in Europe (CIDREE) Yearbook 2015, 136-153. Retrieved from:

http://www.oph.fi/download/173262_cidree_yb_2015 halinen_harmanen_mattila.pdf

Hufnagel, E., \& Kelly, G. J. (2017). Examining emotional expressions in discourse: Methodological considerations. Cultural Studies of Science Education, 1-20. doi:10.1007/s11422-017-9806-4

Huhtamäki, E., Holma, H., Nokelainen, P., \& Kumpulainen, K. (2017). Otos iloa - Lasten näkökulmia iloa tuottavista peruskoulun oppimisympäristöistä. Kasvatus, 48(4), 336352.

Izard, C. E. (1977). Human emotions. New York: Plenum Press.

Jacobs, G. E. (2013). Reimagining multiliteracies: A response to Leander and Boldt. Journal of Adolescent \& Adult Literacy, 57(4), 270-273.

Kalantzis, M., \& Cope, B. (2005). Learning by design. Melbourne, Australia: Victorian Schools Innovation Commission.

Kangas, M. (2010). Finnish children's views on the ideal school and learning environment. Learning Environments Research, 13(3), 205-223.

Kelly, G. J. (2016). Methodological considerations for the study of epistemic cognition in practice. In J. A. Greene, W. A. Sandoval \& I. Braten (Eds.), Handbook of epistemic cognition (pp. 393-408). New York: Routledge.

Keltner, D., \& Gross, J. J. (1999). Functional accounts of emotions. Cognition and Emotion, 13, 467-480. doi:10.1080/026999399379140 
Krokfors, L., Kangas, M., Vitikka, E., \& Mylläri, J. (2010). Näkökulmia koulupedagogiikkaan. In R. Smeds, L. Krokfors, H. Ruokamo, \& A. Staffans (Eds.) InnoSchool - Välittävä koulu: Oppimisen verkostot, ympäristöt ja pedagogiikka. SimLab Report Series 31. Aalto-yliopiston teknillinen korkeakoulu. Tuotantotalouden laitos, 51-85.

Konu, A. (2002). Oppilaiden hyvinvointi koulussa. Acta Universitatis Tamperensis 887.

Kumpulainen, K., Krokfors, L., Lipponen, L., Tissari, V., Hilppö, J., \& Rajala, A. (2010). Oppimisen sillat: Kohti osallistavia oppimisympäristöjä. Helsingin yliopisto. CICERO Learning/Oppimisen sillat-hanke.

Kumpulainen, K., Lipponen, L., Hilppö, J. \& Mikkola, A. (2014). Building on the positive in children's lives: A co-participatory study on the social construction of children's sense of agency. Early Child Development and Care, 184(2), 211-229.

Kumpulainen, K., Mikkola, A., Rajala, A., Hilppö, J. \& Lipponen, L. (2014). Positiivisen pedagogiikan jäljillä: Myönteisten kokemusten neuvottelu osana lasten oppimista ja hyvinvointia edistävää työtä. In L. Uusitalo-Malmivaara (Ed.), Positiivisen psykologian voima. Jyväskylä: PS-Kustannus, 224-242.

Kumpulainen, K., Sintonen, S., Vartiainen, J., Sairanen, H., Nordström, A., Byman, J., \& Renlund, J. (2018). Playful parts: The joy of learning multiliteracies. Helsinki: Kiriprintti Oy.

Kumpulainen, K. (in press). Promoting the Joy of Learning Multiliteracies from Early Years Onwards: An Educational Reform Initiative in Finland. Media Education Research Journal.

Leander, K., \& Boldt, G. (2013). Rereading “a pedagogy of multiliteracies”: Bodies, texts, and emergence. Journal of Literacy Research, 45(1), 22-46. doi:10.1177/1086296X12468587

Liu, W., Tian, L., Huebner, E. S., Zheng, X., \& Li, Z. (2014). Preliminary development of the elementary school students' subjective well-being in school scale. Social Indicators Research, 120(3), 917-937. 
Mesquita, B., \& Albert, D. (2007). The cultural regulation of emotions. In J. J. Gross (Ed.), Handbook of emotion regulation. New York: Guilford Press.

Miller, J. W., \& McKenna, M. C. (2016). World Literacy: How Countries Rank and Why It Matters. New York \& Abingdon: Routledge.

Moll, L. C., Amanti, C., Neff, D., \& Gonzalez, N. (1992). Funds of knowledge for teaching: Using a qualitative approach to connect homes and classrooms. Theory into Practice, 31(2) 132-141. doi:10.1080/00405849209543534

Mullis, I. V. S., Martin, M. O., Foy, P., \& Hooper, M. (2017). PIRLS 2016 International Results in Reading. Chestnut Hill, MA: TIMSS \& PIRLS International Study Center, Boston College. Retrieved from: http://timssandpirls.bc.edu/pirls2016/internationalresults/

Murray, J., \& Palaiologou, I. (2018). Young children's emotional experiences. Early Child Development and Care, 188(7), 875-878. doi:10.1080/03004430.2018.1449839

New London Group. (1996). A pedagogy of multiliteracies: Designing social futures. Harvard Educational Review, 66(1), 60-93. doi:10.17763/haer.66.1.17370n67v22j160u

Nicholson, S. (1971). How not to cheat children, the theory of loose parts. Landscape Architecture, 62(1), 30-34.

Oatley, K. (1993). Social constructions of emotions. In M. Lewis \& J. M. Haviland (Eds.), Handbook of emotions (pp. 341-352). New York: Guilford Press.

Parkinson, B. (1995). Ideas and realities of emotion. London: Routledge.

Parry, B. (2013). Children, film and literacy. London: Palgrave.

Pekrun, R., Elliot, A. J., \& Maier, M. A. (2006). Achievement goals and discrete achievement emotions: A theoretical model and prospective test. Journal of Educational Psychology, 98(3), 583-597.

Pekrun, R., Goetz, T., Titz, W., \& Perry, R. P. (2002). Academic emotions in students' selfregulated learning and achievement: A program of qualitative and quantitative research. Educational Psychologist, 37, 91-105. 
Potter, J. (2011). New literacies, new practices and learner research: Across the semipermeable membrane between home and school. Journal of Lifelong Learning, XVI (3), 21-35.

Potter, J., \& McDougall, J. (2017). Digital media, culture and education. Theorising third space literacies. London: Palgrave Macmillan UK.

Rantala, T. (2006). Oppimisen iloa etsimässä. Opetus 2000. Jyväskylä: PS-kustannus.

Ryan, R. M., \& Deci, E. L. (2000). Self-Determination Theory and the Facilitation of Intrinsic Motivation, Social Development, and Well-Being. American Psychologist, $55(1), 68-78$.

Scherer, K. R. (2009). The dynamic architecture of emotion: Evidence for the component process model. Emotion, 23, 1307-1351.

Serafini, F., \& Gee, E. (2017). Remixing multiliteracies. Theory and practice from New London to New Times. New York: Teachers College Press.

Shuman, V., \& Scherer, K. R. (2014). Concepts and structures of emotions. In P. A. Alexander, R. Pekrun, \& L. Linnenbrink-Garcia (Eds.), International Handbook of Emotions in Education. Abingdon: Routledge. Retrieved from: https://www.routledgehandbooks.com/doi/10.4324/9780203148211.ch2

Seligman, M. E., \& Csikszentmihalyi, M. (2000). Positive psychology: An introduction. American Psychologist, 55(1), 5-14.

Seligman, M. E., Ernst, R. M., Gillham, J., Reivich, K., \& Linkins, M. (2009). Positive education: Positive psychology and classroom interventions. Oxford Review of Education, 35(3), 293-311.

Sintonen, S., Kumpulainen, K. \& Vartiainen, J. (2018). Young children's imaginative play and dynamic literacy practices in the digital age. In G. Oakley (Ed.), Mobile technologies in children's language and literacy: Innovative pedagogy in preschool and primary education (pp. 15-28). Bingley, UK: Emerald Publishing Limited.

Spradley, J. P. (1980). Participant observation. New York: Harcourt Brace Jovanovich College Publishers. 
Stone, L. D., \& Thompson, G. A. (2014). Classroom mood and the dance of stance: The role of affective and epistemic stancetaking in the development of a classroom mood. Learning, Culture and Social Interaction, 3(4), 309-322.

TENK [The Finnish Advisory Board on Research Integrity]. (2012). Responsible conduct of research and procedures for handling allegations of misconduct in Finland. Guidelines of the Finnish Advisory Board on Research Integrity. Helsinki.

Tomkins, S. S. (1962). Affect, imagery and consciousness. Vol. 1: The positive affects. New York: Springer.

Uusitalo-Malmivaara, L. (2014). Positiivinen psykologia - mitä se on? In L. UusitaloMalmivaara (Ed.) Positiivisen psykologian voima. Jyväskylä: PS-Kustannus, 18-27.

Vygotsky, L. S. (1962). Thought and language. Cambridge, MA: MIT Press.

White, R. (2012). The power of play: A research summary on play and learning. St. Paul, $\mathrm{MN}$ : Minnesota Children's Museum.

Zembylas, M. (2016). Making sense of the complex entanglement between emotion and pedagogy: Contributions of the affective turn. Cultural Studies of Science Education, 11, 539-550. doi:10.1007/ s11422-014-9623-y 